\title{
Completion norms for 329 sentence contexts
}

\author{
PAUL A. BLOOM and IRA FISCHLER \\ University of Florida, Gainesville, Florida 32611
}

\begin{abstract}
Completion responses were collected for two sets of sentence contexts, which were designed to produce different distributions of probabilities for the primary responses. The subject population consisted of undergraduate college students. For each context, responses and their respective probability of occurrence are listed, and an index of the primary responses is provided. It is hoped that these normative materials will facilitate comparison among future studies of the effects of sentence contexts on word processing.
\end{abstract}

Meaning is conveyed in language through sequences of words. The study of the relationship between comprehension of meaning and the processing of individual words has taken several forms in contemporary psychological research. A common method involves presenting literate subjects with contexts in the form of incomplete sentences. In educational research, Taylor's (1953) "cloze" method has been widely used: Readers are presented prose passages of one or more sentences from which a number of words have been omitted. The reader's task is to fill in the word or words that seem the most appropriate completions of the context. Generally, as the context becomes more informative, in the sense of reducing uncertainty about possible alternative completions (Shannon, 1948), the range of responses elicited from a sample of readers becomes smaller, and any one reader's ability to predict the most probable response increases. This simple procedure has been used to derive measures of text readability (e.g., Bormuth, 1975), assess the amount of information gained from reading a passage (e.g., Coleman \& Miller, 1968; Rubenstein \& Aborn, 1958), and assess the ability of readers of a certain grade level (e.g., Rankin \& Overholzer, 1969) or reading level (e.g., Neville \& Pugh, 1976-1977) to make use of contextual cues in reading.

In psychology, use of cloze-like procedures naturally followed the acceptance within psychology of the concepts of information theory. Miller and Selfridge (1950) had subjects generate sentence-like "approximations to English" in which the words in a sequence were constrained by a variable number of preceding words (n). As the level of constraint increased, acquisition and retention of the passages improved regularly up to about $\mathrm{n}=7$. Similarly, Aborn, Rubenstein, and Sterling (1959) showed that most of the information used in generating cloze completions typically came from within seven or eight words preceding the missing word.

Several studies of word recognition demonstrated

We would like to thank Karen Bryant for her assistance in data collection. Requests for reprints should be addressed to Paul Bloom, Psychology Department, University of Florida, Gainesville, Florida 32611. that a sequence of words in the form of a sentence context (e.g., "Three people were killed in a major highway _) could facilitate or inhibit identification thresholds for subsequently presented words (Morton, 1964; Tulving \& Gold, 1963; Tulving, Mandler, \& Baumel, 1964). More recently, a series of experiments have shown similar effects of sentence contexts on word pronunciation latency (e.g., Stanovich \& West, 1979) and on lexical decision latency (e.g., Fischler \& Bloom, 1979; Schuberth \& Eimas, 1977). Although even very young readers are sensitive to contextual constraints provided by a sentence (e.g., Goodman, 1969) and the ability to accurately predict target words does improve with age (see Doehring, 1976) and reading skill (e.g., Perfetti, Goldman, \& Hogaboam, 1979), there is currently some question regarding the extent to which readers use context to process subsequent words: Does the reader anticipate particular words or only expect that the word "make sense" given the meaning of the context? Thus, as skill at recognizing words in isolation becomes more automatic, the information conveyed by the sentence context may have decreasing influence on recognition of particular words.

Evidence for decreasing inhibitory effects of context with increased reading skill was found by West and Stanovich (1978), who showed that inappropriate sentence contexts inhibited vocalization latency of target words for fourth- and sixth-grade readers, but not for college students. (See also Samuels, Begy, and Chen, 1975-1976, for similar results using single-word semantic contexts.) Mitchell and Green (1978) found that transitional probability of words in prose had little effect on self-paced oral reading speed, whereas semantically anomalous words slowed reading substantially. In Fischler and Bloom's (1979) lexical decision experiments, only words that were highly predictable given a sentence context (cloze $p>.90$ ) were facilitated by the sentence context, whereas latency to words that were anomalous completions was strongly inhibited. In a subsequent study, cloze probability of target words had no effect at all when words of the context were presented singly in succession, but the inhibitory effects of 
semantic anomaly were maintained and were seen at fast presentation rates (Fischler \& Bloom, 1980).

The absence of standardized materials in these studies has hindered comparison of the effects of predictability across experiments. Each experimenter has either collected his or her own cloze norms or relied on intuitions about relative congruity between the meaning of the sentence context and target word. Occasionally, such lists contain stimuli in which semantic congruity is confounded with association value between a particular word in the context and the target word. The situation may be contrasted to the availability of norms for singleword associations, which has permitted some standardization in studies of associative processes. Although the set of sentences is unbounded, in contrast to the set of words, sentence contexts can still be generated within specifiable constraints and cloze responses enumerated systematically. The purpose of the present study was to develop two such sets of sentence contexts and report cloze responses to each sentence.

The most likely response word for a given context will be called the primary response. The first set of sentence contexts, which will be called the varieduncertainty (VU) set, was designed to produce a wide range of probabilities for the primary responses, from very highly constrained contexts that would produce very "dominant" or likely primary responses (e.g., "The movie was so jammed they couldn't find a single ") to contexts allowing a large number of alternative completions (e.g., "Seth couldn't imagine anyone less __"). Contexts selected from this set served as stimuli for our initial experiments (Fischler \& Bloom, 1979). Since, in those experiments, facilitatory effects of contexts seemed to be limited to very probable words, a second set of sentences was compiled in which we attempted to keep the cloze probability of the primary response as high as possible, while still allowing for alternative meaningful responses. This set will be called the low-uncertainty (LU) set.

\section{COMPILATION OF VU SET OF CLOZE NORMS}

\section{Method}

Subjects. An introductory psychology class of 100 students participated in the sentence-completion task as part of a course requirement.

Generation of sentence contexts. A set of 120 sentence contexts was written by the experimenters, constrained as follows: (1) Each context could be made into a grammatically acceptable sentence by the addition of a single word; (2) each context was six to eight words long; (3) obvious cliche's were avoided, as were contexts that might produce as frequent responses words that were highly associated to particular words of the contexts (e.g., "A canary is a kind of __. "); (4) over the set of contexts, as noted above, we attempted to obtain a wide range of cloze probabilities for the primary response; (5) a range of syntactic structures was included, so that although all contexts were judged to be natural statements, some were more syntactically complex than others (see Fischler \& Bloom, 1980). However, no formal manipulation of syntactic complexity was attempted.
Procedure. All students were given an identical five-page booklet containing 30 sentence contexts per page. Each context was typed with an underscore and period following the final word of the context. A cover sheet provided a copy of instructions that students could follow as they were read by the experimenter: "On the following pages are a large number of sentences, each with the final word left blank. Your task is simply to read each sentence at your normal rate, and write down the word that first occurs to you as a likely end of that sentence. For example, if the sentence 'frame' were, 'The party did not end until __, possible responses might include 'dawn,' three,' 'late,' 'midnight,' and so forth. Don't try to be either unique or average; just be natural. You should keep within the following bounds, however: (1) Only one response word per sentence; (2) The word should 'make sense' of the sentence, and be from an appropriate class of words (nouns, verbs, adjectives, etc.); (3) English words only; (4) No proper names, hyphenated or contracted words; (5) Try to avoid repetitions. For some of the sentences, the response will seem obvious; for others, any number of words will seem possible. This is of course intentional, since we are interested in the whole range of sentence "constraints." "

\section{Results}

Probability of each response to each sentence context was calculated. Responses with a probability greater than .01 are listed for each context in Appendix A. [An index of the primary responses is provided in Appendix $\mathrm{C}$; corresponding unlikely and anomalous completions used by Fischler and Bloom $(1979,1980)$ are provided in Appendix D.] Sentence contexts are listed in order of decreasing probability of the primary response. A frequency distribution for the probability of the primary response across contexts is presented in Table 1. As intended, the distribution obtained was roughly rectangular, although there were few primary responses with a probability of less than .10 .

The probability of generating a particular response can be considered equivalent to the probability that a particular subject could predict that word, given the context. This probability is the congruity, or $\mathrm{C}$, measure used by Tulving and Gold (1963). Tulving and Gold also derived an information, or I, measure based on the distribution of response probabilities for a given context. Two contexts whose primary responses are equally likely, and which have the same number of alternative

Table 1

Relative Frequency of Probability of Primary Response for Two Sets of Sentence Context

\begin{tabular}{crr}
$\begin{array}{c}\text { Probability of } \\
\text { Response }\end{array}$ & \multicolumn{3}{c}{ Context Set } \\
\cline { 2 - 3 } $.90-1.00$ & 8 & LU \\
$.80-.89$ & 9 & 23 \\
$.70-.79$ & 13 & 19 \\
$.60-.69$ & 10 & 17 \\
$.50-.59$ & 17 & 9 \\
$.40-.49$ & 13 & 11 \\
$.30-.39$ & 13 & 7 \\
$.20-.29$ & 13 & 6 \\
$.10-.19$ & 3 & 5 \\
$.00-.09$ & 1 & 2 \\
\hline
\end{tabular}


responses, can differ in average information content, which increases as alternatives become more equally probable. Tulving and Gold found that when the effect of congruity, the probability that the target word actually shown could be predicted, was controlled, the effect of information content on visual duration thresholds was nonsignificant. This measure was thus not derived for either of our norms.

\section{COMPILATION OF LU SET OF CLOZE NORMS}

\section{Method}

Subjects. Four introductory psychology classes of 80 to 100 students each participated in the sentence-completion task as part of a course requirement.

Generation of sentence contexts. Four sets of 80 sentence contexts were compiled. Fifty contexts were written for each set which seemed likely to produce a very probable primary response, but at the same time allowed at least one alternative semantically acceptable completion. In some cases, sentence contexts from the VU set were modified for this purpose and included in one of the new sets. The remaining 30 of each set were designed to produce a less likely primary response and were included to make the overall appearance of each set more similar to that of the VU set. Some of the 30 "filler" contexts were identical to other contexts from the VU set or to filler contexts in the other LU sets. Our general strategy for writing sentences was to begin with a target response and generate contexts likely to produce that response.

The other constraints used in generating the contexts were the same as those used for the VU set, except that the number of words per context was allowed to vary from 5 to 10 .

Procedure. Each set of contexts was presented to $100 \mathrm{stu}$ dents in a format identical to that used for the first set. The same instructions were also used.

\section{Results}

Probability of each response to each unique context not included in the VU set was calculated. Responses occurring with probability greater than .01 are listed along with each context in Appendix B. (An index of primary responses is provided in Appendix C.) The frequency distribution of primary response probabilities across contexts is shown in Table 1 . As intended, the distribution is negatively skewed, with a greater proportion of very probable primary responses than was obtained in the VU set.

\section{DISCUSSION}

The present sets of sentence-completion norms provide a substantial base of standardized materials for investigating the effects of sentence contexts on word processing. One characteristic of sentence contexts, compared with single-word associative contexts, is that very high levels of response probability can be readily obtained. Primary associative responses, in contrast, rarely exceed probabilities of .70 (e.g., Keppel \& Strand, 1970). Thus, although the sentence context "He mailed the letter without a ___ (Context 1, Appendix A) elicited the response "stamp" with a probability of .99 , "letter-stamp" has an associative probability of only .07 (Postman, 1970). Similarly, "baby" elicits "mother" with a probability of .04 (Keppel \& Strand, 1970), but "The baby cried and upset her __ elicits "mother" with a .75 probability (Context 27 , Appen$\operatorname{dix}$ A). Therefore, it is unlikely that associative strength between context and response words is responsible for the present results.

In the present study, each group of subjects (one VU group and four LU groups) received an identical set of sentence contexts. Although one may argue that this procedure may limit the generality of the present results, a high correspondence between responses for the sentence contexts appearing at different positions on different lists was found. Thus, for example, the correlation between the responses for the sentence context "Larry chose not to join the __ (Context 90, Appendix A, VU set) and the responses for the same context at different positions on the four LU lists was +.94 . Similarly, the correlation between the responses for the context "Their picnic was ruined by the (Context 304, Appendix B, LU set) and those for the same context at different positions on the other three LU lists was +.99 .

There are, of course, similarities between the sentence-completion task and other semantic production tasks, such as the category norms of Battig and Montague (1969). Many of the contexts seemed to produce responses that could be grouped in an ill-defined semantic category. For example, completions of the context "Rushing out he forgot to take his " (Context 111, Appendix A) seemed to belong to the category of "transportable personal belongings." However, responses to other contexts suggest a more productive nature for sentence completions than for single-word associations. For example, it is difficult to imagine what single category is represented by the responses "dress," "floor," "broom," and "patio" (Context 93, Appen$\operatorname{dix} A$, "She cleaned the dirt from her ___") or the responses "office," "job," and "convenience" (Context 18, Appendix A, "She called her husband at his ").

The norms obtained are descriptive of the knowledge base of the population of college-aged students. It seems likely that completion norms for other populations, such as children or nonstudents, would diverge considerably from the present norms. Few parents, for example, would complete Context 406 (Appendix B), "Even infants can be taught to __ with the response "read." Use of these norms with populations other than the one sampled should be done with caution.

With the present population sampled, subjects had little difficulty in comprehending the sentence contexts. The vast majority of responses appeared consistent with at least one meaning of the corresponding contexts. There were exceptions, such as with a context not included in the norms, "The compost enriched the 
," which produced such responses as "soup" and "mind." Whether this reflected a failure of comprehension or a glimmer of creative processing could not be determined.

As noted above, although particular words may be more or less probable in context, it is unclear to what extent readers make use of this information. In a separate study (Fischler, Note 1), however, we have shown at least that individual subjects can predict the probability of a primary response with reasonable accuracy. This means that subjects would have available some information about how likely they would be to accurately predict successive words of a sentence.

\section{REFERENCE NOTE}

1. Fischler, I. Ratings of cloze response dominance. Unpublished study, University of Florida, 1979.

\section{REFERENCES}

Aborn, M., Rubenstein, H., \& Sterling, T. D. Sources of contextual constraint upon words in sentences. Journal of Experimental Psychology, 1959, 57, 171-180.

Battig, W. F., \& Montague, W. E. Category norms of verbal items in 56 categories: A replication and extension of the Connecticut norms. Journal of Experimental Psychology, 1969, 80(3, Pt. 2), 1-46.

Bormuth, J. Literacy in the classroom. In W. D. Page (Ed.), Help for the reading teacher: New directions in research. Urbana, III: ERIC Clearinghouse on Reading and Communication, 1975.

Coleman, E. B., \& Miller, G. R. A measure of information gained during prose learning. Reading Research Quarterly, 1968, 3, 369-386.

DoenRing, D. G. Acquisition of rapid reading responses. Monographs of the Society for Research in Child Development, 1976, 41(2, Serial No. 165).

Fischler, I., \& Bloom, P. A. Automatic and attentional processes in the effects of sentence contexts on word recognition. Journal of Verbal Learning and Verbal Behavior, 1979, 18, 1-20.

Fischler, I., \& Bloom, P. A. Rapid processing of the meaning of sentences. Memory \& Cognition, 1980, 8, 216-225.

Goodman, K. S. Analysis of oral reading miscues: Applied psycholinguistics. Reading Research Quarterly, 1969, 5, 9-30.
Ke Ppel, G., \& Strand, B. Z. Free-association responses to the primary responses and other responses selected from the PalermoJenkins norms. In L. Postman \& G. Keppel (Eds.), Norms of word association. New York: Academic Press, 1970.

Miller, G. A., \& Selfridge, J. A. Verbal context and the recall of meaningful material. American Journal of Psychology, 1950, 63, 176-185.

Mitchell, D. C., \& Green, D. W. The effects of context and content on immediate processing in reading. Quarterly Journal of Experimental Psychology, 1978, 30, 609-636.

Morton, J. The effects of context on the visual duration thresholds for words. British Journal of Psychology, 1964, 55, 165-180.

Neville, M. H., \& Pugh, A. K. Context in reading and listening: Variations in approach to cloze tasks. Reading Research Quarterly, 1976-1977, 12, 13-31.

Perfett, C. R., Goldman, S. R., \& Hogaboam, T. W. Reading skill and the identification of words in discourse context. Memory \& Cognition, 1979, 7, 273-282.

Postman, L. The California norms: Association as a function of word frequency. In L. Postman \& G. Keppel (Eds.), Norms of word association. New York: Academic Press, 1970.

Rankin, E. F., \& Overholzer, B. M. Reaction of intermediate grade children to contextual cues. Journal of Reading Behavior, 1969, 1, 50-73.

Rubenstein, H., \& Aborn, M. Learning, prediction and readability. Journal of Applied Psychology, 1958, 42, 28-32.

Samuels, S. J., Begy, G., \& Chen, C. C. Comparison of word recognition speed and strategies of less-skilled and more highly skilled readers. Reading Research Quarterly, 1975-1976, 11, 72-86.

Schuberth, R. E., \& Eimas, P. D. Effects of context on the classification of words and nonwords. Journal of Experimental Psychology: Human Perception and Performance, 1977, 3, 27-36.

Shannon, C. E. A mathematical theory of communication. Bell System Technical Journal, 1948, 27, 379-423; 623-656.

Stanovich, K. E., \& WEST, R. F. Mechanisms of sentence context effects in reading: Automatic activation and conscious attention. Memory \& Cognition, 1979, 7, 77-85.

TAYLOR, W. L. "Cloze" procedure: A new tool for measuring readability. Journalism Quarterly, 1953, 30, 415.

Tulving, E., \& Gold, C. Stimulus information and contextual information as determinants of tachistoscopic recognition of words. Journal of Experimental Psychology, 1963, 66, 319-327.

Tulving, E., Mandler, G., \& Baumel, R. Interaction of two sources of information in tachistoscopic word recognition. Canadian Journal of Psychology, 1964, 18, 62-71.

West, R. F., \& Stanovich, K. E. Automatic contextual facilitation in readers of three ages. Child Development, 1978, 49, 717-727.

Appendix A

Completion Norms for 120 Sentence Contexts

1. (.01) He mailed the letter without a STAMP (.99).

2. (.01) Captain Sheir wanted to stay with the sinking SHIP (.97) RAFT (.02).

3. (.04) In the first space enter your NAME (.96). (.02).

4. (.02) They went as far as they COULD (.96) DARED (.02).

5. (.05) The old house will be torn DOWN (.93) APART

6. (.06) Most cats see very well at NIGHT (.92) CLIMBING (.02).

7. (.08) It's hard to admit when one is WRONG (.92).

8. (.06) Jean was glad the affair was OVER (.92) FINISHED (.02).

9. (.05) Her job was easy most of the TIME (.91) DAY
10. (.03) The whole town came to hear their mayor SPEAK (.90) TALK (.07).

11. (.06) When you go to bed turn off the LIGHT(S) (.89) RADIO (.03) STEREO (.02).

12. (.03) Most shark attacks occur very close to SHORE (.88) LAND (.07) WATER (.02).

13. (.04) The game was called when it started to RAIN (.88) SNOW (.05) LIGHTNING (.03). (.07).

14. (.05) None of his books made any SENSE (.88) MONEY

15. (.09) He scraped the cold food from his PLATE (.87) DISH (.04)

16. (.07) The dough was put in the hot OVEN (.85) SUN (.04) GREASE (.02) PAN (.02).

17. (.02) The dispute was settled by a third PARTY (.85) (.04). 
Appendix A (Continued)

PERSON (.09) OPINION (.02) VOTE (.02)

18. (.03) She called her husband at his OFFICE (.85) JOB (.10) CONVENIENCE (.02).

19. (.05) Three people were killed in a major highway ACCIDENT (.84) COLLISION (.05) CRASH (.04) MISHAP (.02).

20. (.10) All the guests had a very good TIME (.83) DINNER (.03) EVENING (.02) MEAL (.02).

21. (.06) The wealthy child attended a private SCHOOL (.82) PARTY (.06) ACADEMY (.04) INSTITUTION (.02). 22. $(.02)$ The crime rate has gone up this YEAR (.79) MONTH (.11) CITY (.03) WEEK (.03) SUMMER (.02).

23. (.04) New York is a very busy CITY $(.78)$ PLACE $(.10)$ TOWN (.05) METROPOLIS (.03). (.17)

24. (.05) Her new shoes were the wrong SIZE $(.78)$ COLOR

25. (.06) The hungry bear found some stale BREAD $(.76)$ MEAT (.07) CRACKERS (.03) FOOD (.03) HONEY (.03) SANDWICHES (.02).

26. (.08) The grocer checked his stock before going HOME (.75) OUT (.08) SHOPPING (.07) OUTSIDE (.02).

27. (.12) The baby cried and upset her MOTHER (.75) STOMACH (.03) BOTTLE (.02) CUP (.02) MILK (.02) PARENTS (.02) SITTER (.02).

28. (.06) We sprayed the yard to keep away the BUGS (.74) INSECTS (.07) DOGS (.05) ANTS (.03) FLIES $(.03)$ MOSQUITOES (.02).

29. (.06) Seals can swim better than they can WALK $(.74)$ FLY (.05) RUN (.05) CRAWL (.03) TALK (.03) SEE (.02) SING (.02).

30. (.06) He bought them in the candy STORE (.74) SHOP (.14) CANE (.04) MACHINE (.02)

31. (.08) The lawyer feared that his client was GUILTY (.73) LYING (.14) CRAZY (.03) SICK (.02).

32. (.08) George could not believe his son stole a CAR (.71) BIKE (.08) WATCH (.04) BICYCLE (.03) DOLLAR (.02) TOY (.02) TRUCK (.02).

33. (.03) His leaving home amazed all his FRIENDS (.71) FAMILY (.19) RELATIVES (.07).

34. (.03) If the crowd quiets down the band will PLAY (.70) BEGIN (.17) CONTINUE (.04) START (.04) PERFORM $(.02)$.

35. (.07) He crept into the room without a SOUND (.70) NOISE (.10) LIGHT (.05) PEEP (.04) WORD (.04).

36. (.08) At last the time for action had COME (.70) ARRIVED (.20) BEGUN (.02).

37. (.06) Fred sat in his chair on the back PORCH (.69)

ROW (.14) PATIO (.05) LEGS (.04) LAWN (.02).

38. (.12) Billy hit his sister on the HEAD (.69) ARM (.10) NOSE (.07) BUTT (.02).

39. (.10) The dog chased our cat up the TREE (.68) HILL (.14) STREET (.04) LADDER (.02) ROAD (.02).

40. (.07) Too many men are out of WORK (.68) JOBS (.16) MONEY (.04) SHAPE (.03) LINE (.02).

41. (.15) At night they often took a short WALK (.68) BREAK (.05) CUT (.05) NAP (.05) SWIM (.02).

42. (.08) For a runner Ted is rather SLOW (.67) FAST (.10)

FAT (.04) LARGE (.03) BIG (.02) GOOD (.02) HEAVY (.02)

SMALL (.02).

43. (.02) Jack bet all he had on the last RACE (.65) GAME

(.17) HORSE (.10) HAND (.04) CARD (.02).

44. (.18) It was clear that the leg was BROKEN (.64)

INFECTED (.05) AMPUTATED (.03) GONE (.03) INJURED

(.03) FRACTURED (.02) HURT (.02)

45. (.07) Lois is taller than most GIRLS (.63) BOYS (.10)

PEOPLE (.10) WOMEN (.08) GUYS (.02).

46. (.06) They wanted their parents to come HOME (.62)

OVER (.08) VISIT (.06) TOO (.04) DOWN (.03) UP (.03)

ALSO (.02) BACK (.02) SOON (.02) YESTERDAY (.02)
47. (.03) The surgeon tried vainly to save his PATIENT

(.61) LIFE $(.34)$ SON $(.02)$.

48. (.03) You can't take the test without a PENCIL (.61) PEN (.36).

49. (.14) They were startled by the sudden NOISE (.59) CRASH (.07) EXPLOSION (.05) SCREAM (.05) THUNDER (.04) BANG (.03) SOUND (.03).

50. (.09) A large stone blocked the entrance to the CAVE (.58) HOUSE (.10) DRIVEWAY (.07) ROAD (.07) DOOR (.04) GARAGE (.03) DRIVE (.02).

51. (.03) Not even the cast liked the PLAY (.58) SCRIPT (.17) SHOW (.11) PERFORMANCE (.04) PRODUCTION (.03) DIRECTOR (.02) STORY (.02)

52. (.18) Some people have never had a square MEAL (.58) DANCE (.15) DEAL (.09).

53. (.12) He smiled and sat down at the TABLE (.57) BAR (.16) COUNTER (.04) DESK (.04) PARTY (.03) BENCH (.02) PIANO (.02).

54. (.04) Without food a man would die in several DAYS (.56) WEEKS (.37) MONTHS (.03)

55. (.03) Jeff was sent to bed without DINNER (.55) SUPPER (.38) DESSERT (.02) FOOD (.02).

56. (.08) To tune your car you need a special TOOL (.5S) INSTRUMENT (.14) MECHANIC (.08) DEVICE (.05) KIT (.05) WRENCH (.03) MACHINE (.02).

57. Bob would often sleep during his lunch HOUR (.54) BREAK (.41) PERIOD (.05).

58. (.14) Paul has always wanted to be a DOCTOR (.54) LAWYER (.09) SINGER (.07) STAR (.05) DENTIST (.03) COP (.02) CLOWN (.02) JUGGLER (.02) PSYCHOLOGIST (.02) 59. (.10) Diane slowly sank into the hot TUB (.54) BATH (.24) WATER (.10) SHOWER (.02).

60. (.05) Our new green car blocked the narrow DRIVEWAY (.53) DRIVE (.11) ROAD (.11) ALLEY (.08) STREET (.07) PATH (.03) ENTRANCE (.02).

61. (.05) Her dress was made of very fine SILK (.53) MATERIAL (.21) LINEN (.06) SATIN (.06) CLOTH (.05) COTTON (.02) VELVET (.02).

62. (.04) Jill looked back through the open DOOR(S) (.53) WINDOW (.41) GATE (.02).

63. (.22) The choir sang hymns while the people LISTENED (.52) PRAYED (.14) CLAPPED (.05) HUMMED (.04) WATCHED (.03).

64. (.10) Most students prefer to work during the DAY (.51) NIGHT (.15) SUMMER (.13) EVENING(S) (.09) WEEK $(.02)$.

65. (.08) Don found that he had no spare TIRE (.51) CHANGE (.24) TIME (.13) KEY(S) (.02) MONEY (.02).

66. (.11) After speaking Allen left the noisy ROOM (.50) AUDITORIUM (.17) HALL (.08) CROWD (.07) CLASS (.03) CONGREGATION (.02) PARTY (.02).

67. (.09) My uncle gave my mother a big KISS $(.50) \mathrm{HUG}$ (.39) ROSE (.02).

68. (.07) Dan caught the ball with his HAND(S) (.49) GLOVE (.32) MITT (.08) TEETH (.04).

69. (.14) The loaf was eaten except for a small PIECE (.49) CRUMB (.09) PORTION (.08) CRUST (.06) SLICE (.06) BITE (.03) PART (.03) END (.02).

70. (.07) Few nations are now ruled by a KING (.48) DICTATOR (.25) MONARCH(Y) (.08) PRESIDENT (.05) DEMOCRACY (.04) QUEEN (.03).

71. (.04) Harriet sang while my brother played the PIANO (.48) GUITAR (.34) FLUTE (.04) HARP (.03) ORGAN (.03) BANJO (.02) HARMONICA (.02).

72. (.02) The pain she felt was all in her HEAD (.48) MIND (.26) HEART (.06) LEG(S) (.06) SIDE (.03) STOMACH (.03) ASS (.02) BACK (.02) BODY (.02).

73. My aunt likes to read the daily PAPER (.47) NEWSPAPER(S) (.31) NEWS (.22). 
74. John poured himself a glass of MILK (.46) WINE (.26) WATER $(.23)$ BEER $(.03)$ GIN $(.02)$.

75. (.05) The earth is shaped like a BALL (.44) SPHERE (.23) EGG (.09) PEAR (.09) BALLOON (.04) CIRCLE (.03) GLOBE (.03).

76. (.16) In the park the hippie touched the FLOWER(S) (.44) TREE(S) (.17) STATUE (.07) BENCH (.03) CHILD (.03) GRASS (.03) LEAVES (.03) FOUNTAIN (.02) GIRL (.02).

77. (.09) The hunter shot and killed a large DEER (.43) BEAR (.36) MOOSE (.05) ELEPHANT (.03) ANIMAL (.02) BUCK (.02).

78. (.10) Some of the ashes dropped on the FLOOR (.43) RUG (.26) CARPET (.15) GROUND (.03) TIED (.03).

79. (.06) The birds in the yard ate every last CRUMB (.42) SEED (.23) BIT (.11) WORM (.05) BERRY (.03) MORSEL (.03) PIECE (.03) DROP $(.02)$ ONE (.02).

80. (.05) Plants will not grow in dry SOIL $(.42)$ WEATHER (.23) CLIMATE(S) (.16) LAND(S) (.03) SAND (.03) AIR (.02) DIRT (.02) GROUND (.02) PLACES (.02).

81. (.12) Hank reached into his pocket to get the MONEY (.41) KEY(S) (.19) CHANGE (.08) DIME (.04) GUM (.04) KNIFE (.04) GUN (.03) WATCH (.03) JOINT (.02).

82. (.26) Suzy liked to play with her toy DOLL(S) (.41) DOG (.09) ANIMAL(S) (.05) POODLE (.05) DUCK (.04) TRUCK(S) (.04) BOAT (.03) CAR (.03).

83. (.10) The wooded lake made a pretty SCENE (.41) PICTURE (.20) SITE (.15) SETTING (.06) VIEW (.05) BACKGROUND (.03).

84. (.08) Joan showed her friend a new card TRICK $(.40)$ GAME (.25) CATALOGUE (.08) TABLE (.06) TODAY (.04) BOX (.02) DESIGN (.02) HOLDER (.02) YESTERDAY (.02).

85. (.08) They rested under a tree in the SHADE (.38) PARK (.30) YARD (.09) WOODS (.04) MEADOW (.03) ORCHARD (.03) FIELD (.02) FOREST (.02).

86. (.11) Even their friends were left in the DARK (.37) COLD (.24) RAIN (.13) ROOM (.04) CAR (.03) CROWD (.02) DUST $(.02)$ HOUSE $(.02)$ STORE $(.02)$.

87. (.24) The final score of the game was TIED (.37) CLOSE (.09) EVEN (.04) GREAT (.03) HIGH (.03) OUTRAGEOUS (.03) 0-0 (.03) BAD (.02) EMBARRASSING (.02) LOW (.02) POSTED (.02) UNBELIEVABLE (.02) WRONG (.02) ZIP (.02).

88. (.09) Helen reached up to dust the SHELF(VES) (.37) CABINET(S) (.18) MANTLE (.15) LAMP (.06) COUNTER (.05) CEILING (.02) CHAIR (.02) CLOSET (.02) CHANDELIER (.02) TABLE $(.02)$.

89. (.19) Barry wisely chose to pay the BILL (.36) FINE (.21) MAN (.05) PRICE (.05) DEBT (.04) TICKET (.04) CASHIER (.03) WAITER (.03).

90. (.08) Larry chose not to join the CLUB (.34) ARMY (.33) TEAM (.08) FRATERNITY (.07) GROUP (.06) CROWD (.02) NAVY (.02).

91. (.10) The person who caught the thief deserves our THANKS (.34) PRAISE (.32) REWARD (.09) CONGRATULATIONS (.05) GRATITUDE (.04) RECOGNITION (.04) APPRECIATION (.02).

92. (.22) Jim had learned the special passage by HEART (.33) MEMORY (.21) MEMORIZATION (.06) ACCIDENT (.05) NOON (.04) ROTE (.03) READING (.02) SHAKESPEARE (.02) STUDYING $(.02)$.

93. (.17) She cleaned the dirt from her SHOE(S) (.33) DRESS (.11) SHIRT (.09) HANDS (.07) BLOUSE (.04) FLOOR (.04) PANTS (.03) BROOM (.02) CAR (.02) CARPET (.02) HAIR (.02) PATIO (.02) RUG (.02).

94. (.13) Every month Rick had to clean his ROOM (.32) CAR (.26) CLOSET (.09) GUN(S) (.06) GARAGE (.05) SHOES (.03) BODY (.02) RIFLE (.02) TEETH (.02).
95. (12) The car stalled because the engine failed to START (.32) RUN (.19) FIRE (.05) TURN OVER (.05) WORK (.05) IGNITE (.04) TURN (.04) CRANK (.03) IDLE (.03) ACCELERATE $(.02)$ CATCH $(.02)$ COOL $(.02)$ FUNCTION (.02).

96. (.05) He drove the nail into the WOOD (.32) BOARD (.30) WALL (.30) PLANK (.03).

97. (.10) Ken built his new house on a quiet LAKE (.32) STREET (.15) HILL (.13) LOT (.11) HILLSIDE (.08) MOUNTAIN (.06) FARM (.03) ISLAND (.02).

98. (.03) Coming in he took off his COAT (.31) HAT (.21) SHOES (.15) JACKET (.11) SHIRT (.09) CLOTHES (.05) PANTS (.03) BOOTS (.02).

99. (.10) The young boy was granted a small ALLOWANCE (.30) FAVOR (.10) REWARD (.09) WISH (.09) PRIZE (.08) GIFT (.04) LOAN (.04) FORTUNE (.03) PENSION (.03) SUM (.03) AMOUNT (.02) PRIVILEGE (.02) TROPHY (.02). 100. (.10) The death of his dog was a great SHOCK $(.29)$ TRAGEDY (.23) LOSS (.18) SORROW (.05) BLOW (.04) DISASTER (.04) MISFORTUNE (.03) DISAPPOINTMENT (.02) SURPRISE $(.02)$.

101. (.01) You could count on Dale on being late for CLASS (.28) EVERYTHING (.26) ANYTHING (.14) DINNER (.13) SCHOOL (.06) PRACTICE (.03) WORK (.03) APPOINTMENTS (.03) BREAKFAST (.03).

102. (.04) My sister bought tickets for the opening GAME (.27) SHOW (.22) NIGHT (.19) PLAY (.13) PERFORMANCE (.09) BALL (.02) CEREMONY(IES) (.02) CONCERT (.02).

103. (.25) There are times when life seems DULL $(.27)$ BORING (.07) HOPELESS (.07) HARD (.06) USELESS (.06) FUTILE (.04) WORTHLESS (.04) DRAB (.03) EMPTY (.03) DIFFICULT (.02) ENDLESS (.02) IMPOSSIBLE (.02) POINTLESS (.02).

104. (.24) The long test left the class EXHAUSTED (.26) TIRED (.21) DRAINED (.12) DAZED (.07) WEARY (.04) BORED (.02) SPEECHLESS (.02) STUNNED (.02).

105. (.09) The kind old man asked us to STAY (.26) HELP (.21) LEAVE (.10) DINNER (.05) COME (.04) GO (.03) MOVE (.03) SING (.03) DANCE (.02) EAT (.02) LISTEN (.02) LUNCH $(.02)$ SIT $(.02)$ STOP $(.02)$ TALK $(.02)$ WAIT $(.02)$.

106. (.06) The surface of the water was nice and SMOOTH (.26) CALM (.21) COOL (.13) CLEAR (.09) COLD (.09) WARM (.08) CLEAN (.05) GLASSY (.03).

107. (.11) The truck that Bill drove crashed into the TREE (.25) WALL (.24) POST (.15) FENCE (.12) BARN (.03) BRIDGE (.03) CAR (.03) BUILDING (.02) GATE (.02)

108. (.18) His view was blocked by the music STAND $(.25)$ BOX (.10) SHEETS (.07) DIRECTOR (.06) MAN (.06) INSTRUMENT (.05) CONDUCTOR (.04) BAND (.03) EQUIPMENT (.03) MACHINE (.03) BUILDING (.02) GROUP $(.02)$ SPEAKER (.02) STORE (.02) TRUCK $(.02)$.

109. (.13) The storm made the air damp and COLD (.25) COOL (.20) HUMID (.14) MUGGY (.11) HEAVY (.05) MOIST (.04) CHILLY (.03) WET (.03) FRESH (.02).

$110 .(.39)$ The actor was praised for being very GOOD (.24) TALENTED (.12) REALISTIC (.08) CONVINCING (.05) DRAMATIC (.05) EMOTIONAL (.04) NATURAL (.03) BELIEVABLE (.02) CREATIVE (.02) FUNNY (.02) MODEST (.02) PASSIONATE $(.02)$.

111. (.08) Rushing out he forgot to take his COAT (.24) WALLET (.15) LUNCH (.13) BOOKS (.11) KEYS (.10) HAT (.06) VITAMIN (.05) PILL(S) (.04) UMBRELLA (.04).

112. (.14) His ring fell into a hole in the SINK (.23) FLOOR (.18) GROUND (.18) STREET (.09) SEWER (.07) DRAIN (.03) GUTTER (.03) SIDEWALK (.03) ROAD (.02).

113. (.17) He was soothed by the gentle MUSIC (.23) BREEZE (.11) TOUCH (.11) MASSAGE (.10) VOICE (.09) 
Appendix A (Continued)

HAND(S) (.07) NURSE (.02) ROCKING (.02) WAVES (.02) WIND (.02) WOMAN (.02) WORDS (.02).

114. (.16) Every spring they held the annual BALL (.23) PICNIC (.19) FESTIVAL (.14) FAIR (.07) DANCE (.06) CARNIVAL (.05) MEETING (.04) BANQUET (.03) PARTY (.03).

115. (.11) They went to the rear of the long LINE (.22) BUS (.19) TRAIN (.13) HALL (.12) ROOM (.11) CORRIDOR (.05) BOAT (.03) CABIN (.02) HALLWAY (.02).

116. (.22) The judge warned about the dangers of PERJURY (.19) LYING (.16) DRUGS (.11) SPEEDING (.07) DRINKING (.06) CONTEMPT (.04) ALCOHOL (.03) MARIJUANA (.03) POT (.03) PRISON (.02) RAPE (.02) STEALING (.02).

117. (44) Few had the nerve to take the needed SHOT(S) (.19) ACTION (.11) PRECAUTION(S) (.10) STEP(S) (.08) VACCINE (.06) MEDICINE (.05) MONEY (.05) RISK (.03) AMOUNT (.02) FOOD (.02) MEASURE (.02) TIME (.02).
118. (.23) In the distance they heard the THUNDER (.15) TRAIN (.12) SIREN (.10) CRIES (.06) NOISE (.05) CAR(S) (.04) CRASH (.04) SCREAM(S) (.04) BELLS (.03) ROAR (.03) SHOT $(.03)$ SOUND $(.03)$ WHISTLE $(.03)$ VOICE $(.02)$.

119. (.19) They went to see the famous ACTOR (.13) MUSEUM (.07) MAN (.06) STATUE (.06) CIRCUS (.05) PERSON (.05) STAR (.05) LANDMARK (.04) SINGER (.04) SPEAKER (.04) ARTIST (.03) MUSICIAN (.03) PAINTER (.03) SHOW (.03) CLOWN (.02) EXHIBIT (.02) HOUSE (.02) PERFORMER (.02) PLAY (.02).

120, (.41) The police had never seen a man so DRUNK (.09) VIOLENT (.06) NERVOUS (.04) UPSET (.04) UGLY (.04) ANGRY (.03) BEATEN (.03) BIG (.03) MAD (.03) BAD (.02) CRAZY (.02) CRUEL (.02) LOADED (.02) MEAN (.02) MUTILATED (.02) SCARED (.02) STONED (.02) STRONG (.02) TALL (.02).

Note-The numbers in parentheses before the sentences correspond to the summed probabilities of unique responses.

Appendix B

Completion Norms for 209 Sentence Contexts

201. To keep the dogs out of the yard he put up a FENCE (1.00).

202. (.01) The children went outside to PLAY (.99). (.99).

203. (.01) Bill jumped in the lake and made a big SPLASH

204. (.01) Water and sunshine help plants GROW (.99).

205. (.01) At first the woman refused, but she changed her MIND (.99).

206. (.01) The movie was so jammed they couldn't find a single SEAT (.99).

207. (.01) Father carved the turkey with a KNIFE (.99).

208. (.01) She went to the salon to color her HAIR (.99).

209. (.01) The rude waiter was not given a TIP (.99).

210. Sharon dried the bowls with a TOWEL (.98) RAG (.02).

211. (.02) To pay for the car, Al simply wrote a CHECK (.98). (.98).

212. (.02) They sat together without speaking a single WORD (.97).

213. (.03) Fred realized the old house was up for SALE

214. He wondered if the storm had done much DAMAGE (.97) HARM (.03).

215. (.03) Bob proposed, but she turned him DOWN (.97).

216. (.04) Joan fed her baby some warm MILK (.96).

217. (.04) At night the old woman locked the DOOR (.96).

218. (.04) The gas station is about two miles down the ROAD (.96).

219. (.02) He loosened the tie around his NECK (.96) COLLAR (.02).

220. (.04) His job was to keep the sidewalk CLEAN (.96). (.04).

221. The lecture should last about one HOUR (.96) MINUTE

222. John swept the floor with a BROOM (.96) MOP (.04).

223. (.02) His boss refused to give him a RAISE (.96) BONUS (.02). (.04).

224. (.01) The governor vetoed the new BILL (.95) LAW

225. (.03) When the two met, one of them held out his HAND (.95) BADGE (.02).

226. (.05) I could not remember his NAME (.95).

227. (.05) The boat passed easily under the BRIDGE (.95).

228. (.02) The paint turned out to be the wrong COLOR (.94) SHADE (.04).

229. (.03) The kids fed the ducks some stale BREAD (.94) CRUMBS (.03)
230. (.04) He liked lemon and sugar in his TEA (.94) COFFEE (.02).

231. (.02) The gambler had a streak of bad LUCK (.94) BLOOD (.02) TEMPER (.02).

232. (.04) The academic year began in the FALL (.94) SEPTEMBER (.02).

233. (.05) They left the dirty dishes in the SINK (.93) KITCHEN (.02).

234. (.05) The bill was due at the end of the MONTH (.93) HOUR (.02).

235. (.07) They raised pigs on their FARM (.93).

236. (.05) Vic asked her to repeat what she had SAID (.92)

HEARD (.03)

237. (.02) Dillinger once robbed that BANK (.92) TRAIN (.06).

238. (.05) The exit was marked by a large SIGN (.92) ARROW (.03).

239. He lay down and went to SLEEP (.92) BED (.08)

240. (.03) John felt sorry, but it was not his FAULT (.91)

PROBLEM (.04) TURN (.02).

241. (.03) The teacher wrote the problem on the BOARD (.91) BLACKBOARD (.06).

242. (.07) The pigs wallowed in the MUD (.91) PEN (.02)

243. (.03) Ray fell down and skinned his $\operatorname{KNEE(S)~(.91)~}$ ELBOWS (.03) NOSE (.03).

244. (.06) Pam did not have any clothes to WEAR (.90) WASH (.04). (.09).

245. (.01) Shuffle the cards before you DEAL (.90) PLAY

246. (.04) Karen awoke after a bad DREAM (.90) COLD (.03) NIGHTMARE (.03).

247. (.05) When the power went out, the house became DARK (.90) BLACK (.03) QUIET (.02).

248. (.05) Success is often just a matter of hard WORK (.90) LUCK (.03) TRYING (.02).

249. (.03) The pizza was too hot to EAT (.89) HANDLE (.05) ENJOY (.03).

250. (.04) George must keep his pet on a LEASH (.89) DIET (.04) CHAIN (.03).

251. (.01) Yesterday they canoed down the RIVER (.89) RAPIDS (.04) STREAM (.04) LAKE (.02)

252. (.04) The soldier complained that his portion was too SMALL (.89) BIG (.05) LITTLE $(.02)$.

253. (.04) The children held their hands and formed a CIRCLE (.89) LINE (.04) RING (.03). 

(.89).

254. (.11) Jan tried to squeeze in, but there was no ROOM 255. (.04) The movers put the sofa on the bare FLOOR (.89) GROUND (.07).

256. (.04) He was afraid to work the night SHIFT (.89) BEFORE (.07).

257. (.07) The child was born with a rare DISEASE (.88) GIFT (.05).

258. (.04) She tied up her hair with a yellow RIBBON (.88) BOW (.08).

259. (.04) Don't believe everything you HEAR (.88) READ (.05) SAY (.03).

260. (.12) i he parents pleaded with their daughter to come HOME (.88).

261. (.04) The ship disappeared into the thick FOG (.88) MIST (.08).

262. (.08) Joan boiled the eggs in WATER (.88) MINUTES (.02) POT (.02)

263. (.09) The girl knew a lot for her AGE (.88) TEST (.03).

264. (.01) Abby brushed her teeth after every MEAL (.88) DAY (.07) MORNING (.04).

265. (.02) Bill played his stereo much too LOUD(LY) (.87)

OFTEN (.05) LOW (.03) MUCH (.03).

266. (.02) He hung her coat in the CLOSET (.87) RACK (.04) HALL (.03) HOOK (.03).

267. (.02) After dinner they washed the DISHES (.87) CAR (.06) CLOTHES (.05).

268. The squirrel stored some nuts in the TREE (.86) NEST (.08) GROUND (.03) HOLE (.03).

269. (.04) Dick wrote a chapter in the BOOK (.86) DIARY (.04) BIBLE (.03) NOVEL (.03).

270. The piano was out of TUNE (.85) ORDER (.11) KEY (.04).

271. (.05) The winter was very harsh this YEAR (.85) TIME (.04) WINTER (.04) SEASON (.02)

272. He shouted at the top of his LUNGS $(.85)$ VOICE (.15).

273 . The power went out, and all the food went BAD $(.85)$

SOUR (.04) COLD (.03) ROTTEN (.03) SPOILED (.03) STALE (.02).

274. (.03) Our guests should be arriving SOON (.85) NOW (.06) SHORTLY (.04) MOMENTARILY (.02).

275. (.07) I added my name to the LIST (.85) ROSTER (.08).

276. (.08) Sam could not believe her story was TRUE (.84) REAL (.06) TOLD (.02).

277. (.08) The boys helped Jane wax her CAR (.82) FLOOR (.10).

278. (.01) We sometimes forget that golf is just a GAME (.82) SPORT (.17).

279. (.07) The cows moved from the sun into the SHADE (.82) BARN (.06) MOON (.03) NIGHT (.02).

280. (.08) Don't touch the wet PAINT (.81) FLOOR (.08) DOG (.03)

281. (.04) You can't open the door with the wrong KEY (.81) HAND (.09) HANDLE (.03) KNOB (.03).

282. (.01) Tim threw a rock and broke the WINDOW (.81) GLASS (.18).

283. (.07) The old milk tasted very SOUR $(.80)$ BAD $(.10)$ ROTTEN (.03).

284. (.09) Even for an amateur, he was pretty GOOD (.80) BAD (.06) TALENTED (.05).

285. (.06) Jean hurriedly shoved her way through the CROWD (.80) LINE (.10) DOOR (.04).

286. (.01) The better students thought the test was too EASY (.80) HARD (.16) SIMPLE (.03).

287. (.06) Phil put some drops in his $\operatorname{EYE(S)~(.80)~} \operatorname{EAR}(S)$ (.10) NOSE (.04).
288. (.02) The set was so loud he couldn't hear himself THINK (.79) TALK (.15) SPEAK (.04).

289. (.05) Next year my little son will be going to SCHOOL (.79) COLLEGE (.09) KINDERGARTEN (.07).

290. (.03) The train was still on TIME (.79) SCHEDULE (.09) TRACK (.03) COURSE (.02) HOLD (.02) ROUTE (.02). 291. (.12) Fred put the worm on a HOOK (.78) LINE (.04) FISHING POLE (.03) TABLE (.03).

292. (.01) A dog has a good sense of SMELL (.78) HUMOR (.09) DIRECTION (.08) HEARING (.04).

293. (.03) Betsy could never tell a LIE (.78) STORY (.11) JOKE (.08).

294. (.13) A future energy source is the SUN (.78) ANSWER (.05) COAL (.04).

295. (.05) Mrs. Martin told the bad student to stand in the CORNER (.78) HALL (.13) BACK (.04).

296. (.03) The bad boy was sent to his ROOM (.78)

FATHER (.07) HOME (.06) MOTHER (.04) PARENTS (.02).

297. (.07) The child learned to count to TEN (.77) FIVE (.08) ONE HUNDRED (.04) THREE (.04).

298. (.06) It was important to be on TIME (.77) TV (.08) DRUGS (.03) GUARD (.03) TOP (.03).

299. Cathy is liked by all her FRIENDS (.77) PEERS (.13) CLASSMATES (.06) LOVER (.02) TEACHER (.02).

300. (.07) Motorcycles can create a lot of NOISE (.77) ACCIDENTS (.06) FUN (.04) TROUBLE (.04) PROBLEMS (.02).

301. (.13) Through the rain it was hard to read the SIGN(S) (.77) BILLBOARD (.04) PAPER (.04) LETTERS (.02).

302. $(.10) \mathrm{He}$ went to the factory where the toys were MADE (.77) MANUFACTURED (.05) BUILT (.04) PRODUCED (.04).

303. (.09) The man was caught selling an illegal DRUG (.77) ITEMS (.05) BOOK (.03) SUBSTANCE (.03) WEAPON (.03). 304. (.05) Their picnic was ruined by the RAIN (.76) ANTS (.19).

305. (.04) Pete won the cross-country RACE (.76) MEET (.08) EVENT (.04) MARATHON (.02) RELAY (.02) RUN (.02) TOURNAMENT (.02).

306. (.03) When the shooting started, they ran for COVER (.76) SHELTER (.08) HELP (.06) LIFE (.03) IT (.02) SAFETY (.02).

307. (.06) Nothing can beat a bowl of hot SOUP (.75) CHILI (.07) CEREAL (.04) CHOCOLATE (.04) OATMEAL (.04). 308. (.06) While skiing, Randy broke his LEG (.75) ANKLE (.11) ARM (.06) NOSE (.02).

309. (.15) The mole lived in a hole in the GROUND (.74) HILL (.06) TREE (.03) VALLEY (.02).

310. (.02) The sun is just another STAR (.74) PLANET (.21) DAY (.03).

311. (.09) Brian poured some sauce on his rare STEAK (.73) MEAT (.09) DELIGHT (.03) DUCK (.03) RIBS (.03).

312. Hal wrote her a love LETTER (.73) NOTE (.15) SONG (.08) POEM (.04).

313. (.09) Betsy couldn't tell what she was DOING (.73) THINKING (.09) SAVING (.05) EATING (.04).

314. (.03) During the volley, Joe twisted his ANKLE (.73) WRIST (.15) ARM (.07) KNEE (.02).

315. (.11) The sun had turned his hair BLOND(E) (.72) WHITE (.05) RED (.04) GOLD (.02) GREY (.02) LIGHTER (.02) YELLOW (.02).

316. (.02) She was named after her MOTHER (.72) FATHER (.08) GRANDMOTHER (.08) AUNT (.07) MOM (.03).

317. (.02) George had been fired, but he couldn't tell his WIFE (.72) MOTHER (.08) FRIENDS (.06) PARENTS (.06) BOSS (.03) FAMILY (.03).

318. (.09) On his vacation he got some needed REST (.71) 
Appendix B (Continued)

SUN (.06) MONEY (.04) ADVICE (.02) CASH (.02) GAS (.02) HELP (.02) RELAXATION (.02).

319. (.12) Autumn is a good time to buy some new CLOTHES (.71) SHOES (.09) TIRES (.04) BOOTS (.02) LEAVES (.02). 320. (.04) The fertilizer enriched the SOIL (.71) GRASS (.16) GROUND (.07) PLANTS (.02).

321. (.03) It's easy to get lost without a MAP (.70) COMPASS (.21) GUIDE (.06).

322. (.08) They asked Dave to play tennis, but he was too TIRED (.70) BUSY (.06) LAZY (.05) SLOW (.05) BIG (.02) STONED (.02) YOUNG (.02).

323. (.01) The mail should get here SOON (.69) TODAY (.18) EARLY (.03) LATER (.03) NOW (.03) TOMORROW (.03).

324. (.05) He disappeared last year, and has not been SEEN (.68) FOUND (.20) BACK (.04) LOCATED (.03).

325. (.06) He was knocked off his board by the first WAVE (.68) BLOW (.04) BALL (.03) BUMP (.03) HIT (.03) WIND (.03).

326. (.01) The puppy chewed on the BONE (.66) SHOE (.18) RUG (.15).

327. (.11) The front was clearly marked on the weather MAP (.66) CHART (.17) BUREAU (.02) RADAR (.02) REPORT (.02).

328. (.19) Dean's leg was broken, so Ed went to get HELP (.64) DOCTOR (.14) HIM (.03).

329. (.06) The boys were given hamburgers for LUNCH (.63) DINNER (.20) FOOD (.04) SUPPER (.04) REWARD (.03). 330. (.06) David's shirt was made of COTTON (.63) SILK (.18) WOOL (.09) CLOTH (.04).

331. (.02) The old house was built entirely of WOOD (.63) BRICK (.26) STONE (.09).

332. (.05) The rabbit hid in the tall GRASS (.63) BUSH(ES) (.20) TREE (.09) BRUSH (.03).

333. (.06) You'll never achieve anything if you don't TRY (.63) WORK (.20) STUDY (.08) PERSEVERE (.03).

334. (.14) At the track, the handicapper gave me a valuable TIP (.63) LESSON (.09) COIN (.08) HINT (.03) SUGGESTION (.03).

335. (.02) Ellen liked to season her food with SALT (.62) PEPPER (.18) GARLIC (.08) SPICE (.04) OREGANO (.03) PAPRIKA (.03).

336. (.04) The student went home during the BREAK (.62) SUMMER (.08) VACATION (.08) TEST (.05) EXAM (.04) CLASS (.03) DAY (.03) GAME (.03).

337. (.04) They liked to sleep out under the STARS (.61) TREES (.28) MOON (.04) TENT (.03).

338. (.07) During class Jack had to borrow some PAPER (.61) MONEY (.23) PENCILS (.05) NOTES (.04).

339. (.03) Getting the shot didn't really HURT (.61) HELP (.27) MATTER (.09).

340. (.17) Starting a business takes a lot of MONEY (.60) TIME (.12) CAPITAL (.05) PATIENCE (.04) GUTS (.02).

341. (.17) One of the scout troops got LOST (.60) HURT (.04) SHOT (.04) ARRESTED (.03) KILLED (.03) SICK (.03) CAUGHT (.02) FIRED (.02) PROMOTED (.02).

342. (.06) Jim wanted to change the way he LOOKED (.59) ACTED (.08) DRESSED (.08) LIVED (.05) SPOKE (.04) TALKED (.04) WALKED (.04) WAS (.02).

343. (.11) The thick mud stuck to her SHOES (.59) FEET (.11) BOOTS (.09) DRESS (.04) CAR (.03) FACE (.03).

344. (.05) Smoking can give you bad BREATH (.58) LUNGS (.19) HEALTH (.09) COUGH (.05) TASTE (.04).

345. (.03) The pill contained a powerful DRUG (.58) SEDATIVE (.07) STIMULANT (.07) DOSE (.06) INGREDIENT (.06) ANTIDOTE (.04) CHEMICAL (.03) HORMONE (.02) MEDICATION (.02) RELAXANT (.02).

346. (.09) Ira turned on the radio and listened to the MUSIC (.56) NEWS (.24) SONGS (.05) TUNES (.04) DJ (.02).
347. (.19) Jill decided against the car when she learned the PRICE (.56) TRUTH (.11) COST (.06) (GAS) MILEAGE (.02) PROBLEMS (.02) RULES (.02) YEAR (.02).

348. (.07) Mary couldn't leave the parlor until her hair was DRY (.55) DONE (.25) FINISHED (.07) COMBED (.03) DRIED (.03).

349. The rider walked his beautiful HORSE (.54) BIKE (.23) DOG (.13) BRIDE (.04) BICYCLE (.03) MARE (.03).

350. (.04) The apple pie had a delicious TASTE (.54) FLAVOR (.18) AROMA (.09) CRUST (.09) SMELL (.06) 351. (.05) Bob thought she had such a friendly SMILE $(.54)$ PERSONALITY (.15) VOICE (.10) FACE (.09) DISPOSITION (.05) NEIGHBOR (.02).

352. Dick waited and read a BOOK (.54) MAGAZINE (.22) POEM (.05) STORY (.05) PAPER (.04) LETTER (.02) LINE $(.02)$ NEWSPAPER (.02) NOTE (.02) SPEECH (.02).

353. (.12) My father and mother are getting DIVORCED (.54) OLD (.17) ALONG (.06) TIRED (.04) TOGETHER (.03) ANGRY (.02) WORRIED (.02).

354. (.15) The girl was advanced for her AGE (.53) WORK (.11) GRADE (.05) ALLOWANCE (.04) ACHIEVEMENT (.03) EFFORTS (.03) INTELLIGENCE (.03) MONEY (.03).

355. (.08) Scotty licked the bottom of the BOWL (.53) PAN (.09) PLATE (.08) DISH (.06) SPOON (.05) STAMP (.05) POT (.03) SHOE (.03)

356. (.06) She locked the valuables in the SAFE (.53) CAR (.11) TRUNK (.08) VAULT (.06) CHEST (.04) CLOSET (.04) DRAWER (.04) LOCKER (.04).

357. (.15) Surgery was needed to repair his failing HEART (.53) EYESIGHT (.07) SIGHT (.05) KIDNEY (.04) LUNG (.04)

BACK $(.03)$ LIVER (.03) TEETH (.03) VISION $(.03)$.

358. (.03) As soon as they got in, they turned on the LIGHT(S) (.53) TV (.20) RADIO (.07) HEAT (.05) STEREO (.05) AC (.04) IGNITION (.03).

359. (.02) At each table, I had to fill in another FORM (.53) CARD (.17) SHEET (.07) QUESTIONNAIRE (.05) ORDER (.04) GLASS (.03) PAPER (.03) REQUEST (.03) SLIP (.03). 360. (.08) The little girl was afraid of the DARK (.52) DOG (.19) SNAKE (.05) BEAR (.04) CAT (.03) RAIN (.03) THUNDER (.03) WATER (.03).

361. (.08) They took short trips during the SUMMER (.51) WINTER (.07) BREAK (.06) DAY (.06) VACATION $(.06)$ WEEKEND (.06) YEAR (.04) SPRING (.03) WEEK (.03). 362. (.02) The cup of tea felt very WARM (.51) HOT (.28) GOOD (.08) COLD (.04) SOOTHING (.04) NICE (.03).

363. (.07) It was a long class and every one was getting BORED (.50) TIRED (.43).

364. (.17) The pamphlet was missing its COVER (.50) PAGES (.11) POINT (.05) TITLE (.05) STAPLE (.04) BIND (.02) BINDER (.02) FOLDER (.02) MEANING (.02).

365. (.07) He put his feet up on the TABLE (.50) DESK (.20) CHAIR (.12) COUCH (.05) FLOOR (.03) SOFA (.03). 366. (.05) Stan slowed down going around the CORNER (.49) CURVE (.29) TURN (.12) BEND (.05).

367. (.02) What you find depends on where you LOOK (.49) ARE (.32) GO (.10) LIVE (.07).

368. (.11) Jim hit his horse with a WHIP (.49) STICK $(.27)$ CROP (.04) HAMMER (.03) BOARD (.02) REIN (.02) ROPE (.02).

369. (.17) Matt was wild when he was YOUNG DRUNK (.22) MAD (.05) ANGRY (.04) HIGH (.03).

370. (.01) He was miles off the main ROAD (.48) HIGHWAY (.11) STREET (.10) TRACK (.09) DRAG (.06) COURSE (.05) COAST (.03) LAND (.03) PATH (.03).

371. (.06) In the morning Jake took out the GARBAGE (.48) TRASH (.24) DOG (.19) CAR (.03).

372. (.08) Did you want to go to the MOVIES (.47) BATH. ROOM (.11) STORE (.09) PARK (.06) BEACH (.05) ZOO (.05) CIRCUS (.03) PARTY (.03) SHOW (.03). 
373. (.22) On their visit to England, they took a formal TOUR (.47) DRESS (.09) SUITE (.05) GOWN (.04) INVITATION (.04) CRUISE (.03) VISIT (.03) WARDROBE (.03). 374. (.17) Before jogging, it's a good idea to STRETCH (.47) EXERCISE (.12) WARMUP (.12) EAT (.07) REST (.05). 375. (.09) Wally wanted to buy a beer, but he was too YOUNG (.46) BROKE (.21) DRUNK (.09) POOR (.06) CHEAP (.05) FULL (.02) LAZY (.02).

376. (.07) The sandwich wasn't very good without a slice of CHEESE (.45) BREAD (.21) MEAT (.10) HAM (.09) BOLOGNA (.06) TOMATO (.02).

377. (.16) Being stood up made Paul MAD (.44) ANGRY (.29) UPSET (.05) SAD (.04) TALL (.02).

378. (.13) The sail got loose, so they tightened the ROPES (.44) LINE (.10) MAST (.10) SAIL(S) (.07) JIB (.06) STRING (.06) BOW (.02) SHEET (.02).

379. (.02) The senator was startled by the sudden pain in his CHEST (.42) SIDE (.13) BACK (.09) ARM (.07) HEART (.07) ASS (.05) LEG (.05) SHOULDER (.04) ABDOMEN (.03) STOMACH (.03).

380. (.07) To find the body, they had to drain the LAKE (.40) POOL (.20) POND (.13) CANAL (.05) RIVER (.05) DITCH (.04) SINK (.03) WATER (.03).

381. (.15) Rita slowly walked down the shaky LADDER (.39) STAIRS $(.25)$ TREE $(.10)$ STAIRCASE $(.04)$ STEPS (.04) BRIDGE (.03).

382. (.07) She dropped a glass and woke up the BABY (.39) NEIGHBOR (.13) CAT (.11) HOUSE (.09) DOG (.07) FAMILY (.05) KIDS (.05) CHILD (.04).

383. (.05) We used to get company every NIGHT (.37) DAY (.29) WEEK (.10) SUNDAY (.08) WEEKEND (.05) FRIDAY (.03) MONDAY (.03).

384. (.10) A direct attack failed, so they changed the STRATEGY (.37) PLAN(S) (.27) TACTICS (.13) COURSE (.06) PROCEDURES (.04) METHOD (.03).

385. (.33) Their money was divided by the BANK(ER) (.34) MAN (.07) FATHER (.04) LEADER (.04) BOSS (.03) GROUP (.03) LAWYER (.03) TELLER (.03) TREASURER (.03) WILL (.03).

386. (.20) The fire was small, and there was no reason to WORRY (.34) PANIC (.28) LEAVE (.04) RUN (.04) SCREAM (.04) CRY (.03) FEAR (.03).

387. (.04) You can't buy anything for a DIME (.33) DOLLAR (.24) PENNY (.22) NICKEL (.10) NOTHING (.04) GIRL (.03).

388. (.14) He had to fill his truck with GAS (.33) DIRT (.22) SAND (.09) CARGO (.04) CEMENT (.04) MUD (.04) WOOD (.04) HAY (.03) ROCKS (.03).

389. (.14) I thought the sermon was very GOOD (.33) BORING (.24) LONG (.17) INSPIRING (.04) DULL (.02) DUMB (.02) ENLIGHTENED (.02) LENGTHY (.02).

390. (.12) The ruby was so big, it looked like a ROCK (.33) CHERRY (.13) APPLE (.10) STONE (.10) DIAMOND (.06) BALL (.04) MARBLE (.04) ROSE (.04) BOULDER (.02) FAKE (.02).

391. (.17) He wondered if the storm would be OVER (.32) BAD (.19) LONG(ER) (.13) SEVERE (.05) VIOLENT (.05) COMING (.03) DANGEROUS (.03) ROUGH (.03).

392. (.14) The elderly sometimes lose their MIND(S) $(.30)$ MEMORY (.24) HEARING (.19) SENSE(S) (.06) SIGHT (.04) HAIR (.03).

393. (.14) No one wanted to accuse him of STEALING (.29)
MURDER (.18) CHEATING (.12) THEFT (.10) LYING (.07) RAPE (.04) IT (.02) SLANDER (.02) TREASON (.02).

394. (.20) The child went ever higher on the SWING (.28) LADDER (.21) SCALE(S) (.09) MOUNTAIN (.08) BARS (.05) HILL (.03) ROPE (.03) WALL (.03).

395. (.17) He disliked having to commute to the CITY (.27) SCHOOL (.17) OFFICE (.16) JOB (.12) CAMPUS (.04) FACTORY (.04) COLLEGE (.03).

396. (.22) Sometimes success is simply a matter of LUCK (.26) WORK (.15) MONEY (.08) TIME (.08) TRYING (.08) OPINION (.04) ABILITY (.03) DEGREE (.03) PRIDE (.03). 397. (.09) The Smiths had never visited that PLACE (.25) HOUSE (.22) COUNTRY (.09) CITY (.06) FAMILY (.05) RESTAURANT (.04) STATE (.04) TOWN (.04) AREA (.03) MUSEUM (.03) PARK (.03) STORE (.03).

398. (.15) The airplane went into a DIVE (.24) CLOUD (.23)

SPIN (.22) TAILSPIN (.07) HANGER (.05) STORM (.04). 399. (.26) Ample food was made for the PARTY (.22) PICNIC (.09) DINNER (.08) PEOPLE (.06) CROWD (.05) GROUP (.05) GUEST(S) (.05) TRIP (.05) CLUB (.03) CREW (.03) MEAL (.03).

400. (.28) There's something grand about the OPERA (.22)

WEATHER (.08) FLAG (.05) PIANO (.05) CIRCUS (.04)

MOUNTAIN (.04) MOVIES (.04) OCEAN (.04) SOUTH (.04)

CAR (.03) COUNTRY (.03) SUNSET (.03) THEATRE (.03).

401. (.12) The difficult concept was beyond his COMPRE-

HENSION (.22) IMAGINATION (.13) KNOWLEDGE (.11) GRASP (.09) REACH (.09) MIND (.04) SCOPE (.04) UNDERSTANDING (.04) ABILITY (.03) CAPABILITY (.03) REASONING (.03) THOUGHT(S) (.03).

402. (.03) The cigar burned a hole in the COUCH (.20) RUG (.18) CARPET (.13) CHAIR (.11) SEAT (.06) JACKET (.05) TABLE (.05) SOFA (.04) COAT (.03) FLOOR (.03) PANTS (.03) PAPER (.03) SHIRT (.03).

403. (.13) The paper was too thick to CUT (.20) FOLD (.18) READ (.12) TEAR (.10) HOLD (.05) BEND (.04) BURN (.04) CARRY (.04) RIP (.04) ERASE (.02) STAPLE (.02) USE (.02). 404. (.18) I don't know why he didn't take his COAT (.18) HAT (.16) TEST (.11) PILL(S) (.06) UMBRELLA (.06) CAR (.04) MONEY (.04) SHOES (.04) TIME (.04) JACKET (.03) SISTER (.03) WALLET (.03).

405. (.13) The sun went down before we could LEAVE (.18) SEE (.18) FINISH (.16) SWIM (.09) EAT (.06) RETURN (.06) PLAY (.05) ARRIVE (.03) LOOK (.03) TELL (.03).

406. (.19) Even infants can be taught to SWIM (.17) READ (.13) TALK (.13) WALK (.13) SMILE (.07) BEHAVE (.04) LAUGH (.04) LEARN (.04) SPEAK (.04) LISTEN (.02).

407. (.35) His ability to work was GOOD (.14) POOR (.14) AMAZING (.08) EXCELLENT (.05) TREMENDOUS (.05) GREAT (.04) HAMPERED (.04) IMPAIRED (.04) LOW (.04) FANTASTIC (.03).

408. (.24) There was nothing wrong with the CAR (.14) GIRL (.08) TV (.08) FOOD (.05) BOY (.04) CHILD (.04) DINNER (.04) MAN (.04) MEAL (.04) DOG (.03) DOOR (.03) LIGHT(S) (.03) MILK (.03) PAPER (.03) RADIO (.03) TEST (.03).

409. (.44) Seth couldn't imagine anyone less BEAUTIFUL (.09) INTELLIGENT (.08) STUPID (.06) HAPPY (.05) ATTRACTIVE (.04) COMPETENT (.04) IMPORTANT (.04) INTERESTING (.04) AMIABLE (.03) CRUEL (.03) IGNORANT (.03) IMAGINATIVE (.03). 
Appendix C

Index of Primary Responses for Both Norms

\begin{tabular}{|c|c|c|c|c|}
\hline accident (19) & dark $(86,247,360)$ & hook $(291)$ & perjury (116) & stamp (1) \\
\hline action (117) & $\operatorname{day}(s)(54,64)$ & horse (349) & piano (71) & stand (108) \\
\hline actor $(119)$ & deal $(245)$ & hour $(57,221)$ & piece (69) & $\operatorname{star}(s)(310,337)$ \\
\hline age $(263,354)$ & deer $(77)$ & hust (339) & place $(397)$ & start $(95)$ \\
\hline allowance (99) & dime $(387)$ & key $(281)$ & plate (15) & stay $(105)$ \\
\hline ankle $(314)$ & dinnet $(55)$ & king $(70)$ & play $(34,51,202)$ & steak $(31$ i $)$ \\
\hline baby (382) & disease (257) & kiss $(67)$ & porch $(37)$ & stealing (393) \\
\hline bad (273) & dishes (267) & knee(s) (243) & price (347) & store $(30)$ \\
\hline ball $(75,114)$ & dive $(398)$ & knife $(207)$ & race $(43,305)$ & strategy (384) \\
\hline bank(er) $(237,385)$ & divorced (353) & ladder (381) & rain $(13,304)$ & stretch $(374)$ \\
\hline beau tiful (409) & doctor $(58)$ & lake $(97,380)$ & raise $(223)$ & summer $(361)$ \\
\hline bill $(89,224)$ & doing (313) & leash $(250)$ & rest (318) & $\operatorname{sun}(294)$ \\
\hline blonde (315) & doll(s) (82) & leave $(405)$ & ribbon $(258)$ & swim $(406)$ \\
\hline board (241) & door(s) $(62,217)$ & $\operatorname{leg}(308)$ & river $(251)$ & swing (394) \\
\hline bone (326) & down $(5,215)$ & letter $(312)$ & road $(218,370)$ & table $(53,365)$ \\
\hline book $(269,352)$ & dream (246) & lie (293) & rock $(390)$ & taste $(350)$ \\
\hline bored $(363)$ & driveway $(60)$ & $\operatorname{light}(s)(11,358)$ & $\operatorname{room}(66,94,254,296)$ & tea $(230)$ \\
\hline bowt (355) & drug $(303,345)$ & line $(115)$ & rope $(s)(378)$ & $\operatorname{ten}(297)$ \\
\hline bread $(25,229)$ & drunk (120) & list $(275)$ & safe $(356)$ & thanks $(91)$ \\
\hline break (336) & dry $(348)$ & listened (63) & said (236) & think $(288)$ \\
\hline breath (344) & dull (103) & look(ed) $(342,367)$ & sale (213) & thunder $(118)$ \\
\hline bridge (227) & easy (286) & lost (341) & salt (335) & tied $(87)$ \\
\hline broken (44) & eat $(249)$ & loud(ly) (265) & scene $(83)$ & time $(9,20,290,298)$ \\
\hline broom (222) & exhausted (104) & luck $(231,396)$ & school $(21,289)$ & tip $(209,334)$ \\
\hline bugs (28) & eye(s) $(287)$ & lunch $(329)$ & seat (206) & tire $(51)$ \\
\hline $\operatorname{car}(32,277,408)$ & fall $(232)$ & lungs (272) & seen $(324)$ & tired (322) \\
\hline cave $(50)$ & farm $(235)$ & $\operatorname{mad}(377)$ & sense (14) & tool $(56)$ \\
\hline check (211) & fault $(240)$ & $\operatorname{made}(302)$ & shade $(85,279)$ & tour $(373)$ \\
\hline cheese (376) & fence $(201)$ & $\operatorname{map}(321,327)$ & shelf(ves) (88) & towel $(210)$ \\
\hline chest $\{379\}$ & กาo $(78,255)$ & meal $(52,264\}$ & shift $(256)$ & tree $(39,107,268)$ \\
\hline circle (253) & flower(s) (76) & milk $(74,216)$ & ship (2) & trick $(84)$ \\
\hline city $(23,395)$ & fog $(261)$ & mind $(s)(205,392)$ & shock (100) & true $(276)$ \\
\hline class (101) & form (359) & money $(81,340)$ & shoe(s) $(93,343)$ & try (333) \\
\hline clean $(220)$ & friends $(33,299)$ & month $(234)$ & shore (12) & tub (59) \\
\hline closet $(266)$ & game $(102,278)$ & mother $(27,316)$ & $\operatorname{sign}(s)(238,301)$ & tune $(270)$ \\
\hline clothes (319) & garbage (371) & movies (372) & silk (61) & walk $(29,41)$ \\
\hline club $(90)$ & gas (388) & mud (242) & $\operatorname{sink}(112,233)$ & warm $(362)$ \\
\hline coat $(98,111,404)$ & girls $(45)$ & music $(113,346)$ & size $(24)$ & water $(262)$ \\
\hline cold (109) & $\operatorname{good}(110,284,389,407)$ & name $(3,226)$ & sleep (239) & wave $(325)$ \\
\hline color $(228)$ & grass (332) & neck $(219)$ & slow (42) & wear (244) \\
\hline come (36) & ground (309) & night $(6,383)$ & small (252) & whip (368) \\
\hline comprehension $\{401\}$ & grow $(204)$ & noise $(49,300)$ & smell $(292)$ & wife $(3 i 7)$ \\
\hline corner $(295,366)$ & guard (298) & office (18) & smile (351) & window (282) \\
\hline cotton $(330)$ & guilty (31) & opera $(400)$ & smooth (106) & wood $(96,331)$ \\
\hline couch $(402)$ & hair (208) & oven (16) & soil $(80,320)$ & word $(212)$ \\
\hline could (4) & hand (s) $(68,266)$ & over $(8,391)$ & soon $(274,323)$ & work $(40,248)$ \\
\hline cover $(306,364)$ & head $(38,72)$ & paint $(280)$ & sound (35) & worry $(386)$ \\
\hline crowd (285) & hear (259) & рарег $(73,338)$ & soup (307) & wrong (7) \\
\hline crumb (79) & heart $(92,357)$ & party $(17,399)$ & sour $(283)$ & year $(22,271)$ \\
\hline cut (403) & help (328) & patient (47) & speak (10) & young $(369,375)$ \\
\hline damage (214) & home $(26,46,260)$ & pencil (48) & splash (203) & \\
\hline
\end{tabular}

Note-Numbers in parentheses refer to sentence context.

Appendix D

Unlikely and Anomalous Sentence Completions Used by Fischler and Bloom (1979, 1980)

\begin{tabular}{|c|c|c|c|}
\hline 1. check, drill & 14. news, peace & 27. father, surface & 42. poor, flat \\
\hline 2. boat, tone & 15. knife, chain & 28. dogs, cups & 43. deck, site \\
\hline 3. age, love & 17. person, nature & 30. shop, hill & 44. injured, lifted \\
\hline 6. birth, court & 18. number, matter & 31. insane, verbal & 45. males, cells \\
\hline 7. great, young & 19. disaster, graduate & 32. gun, gas & 46. here, best \\
\hline 8. ended, under & 21. church, point & 34. stop, flow & 47. brother, session \\
\hline 10. talk, learn & 22. month, group & 37. yard, stick & 48. review, ballot \\
\hline 11. stove, flesh & 24. kind, wife & 38. back, work & 49. sound, chief \\
\hline 12. Jand, size & 25. food, film & 40. town, feet & 50. mine, corn \\
\hline 13. snow, kill & 26. ou1, long & 41, ride, yote & 53. river, color \\
\hline
\end{tabular}


Appendix D (Continued)

\begin{tabular}{|c|c|c|c|}
\hline 55. dessert, shelter & 70. queen, desk & 89. cost, list & 106. green, round \\
\hline 56. plug, maid & 71. organ, jersey & 90. team, wish & 107. sign, term \\
\hline 57. time, fact & 74. beer, wire & 91. trust, steel & 109. warm, fast \\
\hline 58. dancer, factor & 76. statue, planet & 92. phone, staff & 110. real, small \\
\hline 59. mud, hen & 77. bird, cast & 93. hands, terms & 111. belt, load \\
\hline 60. entrance, sequence & 78. chair, faith & 95. catch, fight & 112. road, bond \\
\hline 61. cloth, sand & 79. grain, trick & 96. wall, moon & 113. woman, total \\
\hline 62. gate, hope & 80. dirt, foam & 97. farm, rose & 114. test, firm \\
\hline 63. followed, employed & 81. candy, motor & 99. privilege, explosive & 115. train, range \\
\hline 64. week, top & 82. drum, bolt & 100. crime, bride & 116. alcohol, buffalo \\
\hline 65. seat, loan & 85. field, earth & 101. lunch, blood & 117. step, rock \\
\hline 66. hall, word & 86. past, form & 103. sick, wise & 118. cannon, walnut \\
\hline 67. ring, bone & 87. high, real & 104. uncertain, defensive & 119. singer, lemon \\
\hline 69. slice, phase & 88. ledge, pearl & 105. wait, race & 120. tense, blank \\
\hline
\end{tabular}

Note-The numbers correspond to the sentence contexts of Appendix A. The two words that follow were used as the unlikely (mean $p=.13$ ) and anomalous (mean $p=.00)$ completions for the indicated context in Fischler and Bloom (1979, 1980). For example, then, context and completion set for Context 1 was "He mailed the letter without a / STAMP/CHECK/DRILL." Of the set of 120 contexts, 96 were actually used in these experiments. For the most part, the unlikely words were selected from actual responses, but because of other constraints, they were occasionally generated by the experimenters. For each sentence, unlikely and anomalous completions matched the primary response in length, number (singular or plural), and number of syllables. Over the set of words, mean frequency of occurrence was equated.

(Received for publication February 21, 1980; revision accepted May 12, 1980.) 